\title{
Incidence of Aeromonas species isolated from different food sources and water.
}

Eid, Hamza M., Amany M. Shalaby ${ }^{1}$ and Samar EL-Sayed Soltan ${ }^{1}$

Departement of Bacteriology, Immunology\&mycology Faculty. Vet Med, Suez Canal University., I Animal Health Research Institute. Port Said Lab Hygiene.

\section{ABSTRACT}

A total number of 350 random samples of raw milk, pasteurized milk, dairy products, tap water and water of udder wash were collected from markets in port- Said Province and examined for prevalence of Aeromonas species using starch ampicillin medium, The incidence of Aeromonas species isolated from raw milk, pasteurized milk, kariesh cheese, dmietta cheese, refrigerated white cheese, tap water and water of udder wash were $58 \%, 26 \%, 70 \%$, $48 \%, 40 \%, 16 \%$ and $68 \%$, respectively. The total number of mesophilic Aeromonas isolates from 350 examined samples was 202 isolates of which 104 (51.5\%) isolates were A. hydrophila, 60 (29.7\%) isolates were A. caviae, 25 (12.4\%) isolates were A. sobria and 11 (5.4\%) isolates were $\boldsymbol{A}$. schubertii. The highest number of isolates (42) were recovered from water of udder wash samples, while the lowest number of isolates were recovered from pasteurized milk and tap water samples. Result of antibiotic sensitivity test revealed high degree of sensitivity towards chloramphenicol, amikacin, ceftriaxone and ciprofloxacin, resistant to ampicillin and colistin sulphate. Result of agarose gel electrophoresis revealed that A. hydrophila, A. caviae and $\boldsymbol{A}$. schubertii have only one plasmid DNA with molecular weight 2.8 kbp While A. sobria was negative for plasmid.

\section{INTRODUCTION}

Motile Aeromonades have been included in the list of bacterial pathogens (Janda et al, 1983 and Holmberg et al, 1986). Buchanan (1984) indicated that the Aeromonades form a group of pathogens, which are emerging as food borne organisms of increasing importance.
Aeromonades are gram-negative rod shape, motile by single polar flagellum, can be isolated from a variety of food, including meat, poultry, milk, milk products, fish, shell fish and vegetables (Melas et $\boldsymbol{a l}$, 1999). And widely distributed in the aquatic environment, including raw and processed drinking water (Holmes et al, 1996). The presence of food borne pathogens in milk is due to direct contact with 
contaminated sources in the dairy farm environment, excretion from the udder of an infected animal or contamination during the processing of milk products (Oliver et al, 2005) Aeromonas hydrophila is the most important species causing disease in humans. They can produce virulence factors including a relatively heat stable cholera-like enterotoxin and heat labile cytotoxic enterotoxin and is recognized as a potential cause of food associated out breaks of gastroenteritis and as etiological agent of acute diarrheal in particular among children (EL-Shenaway and Marth, 1990). Moreover, Aeromonas caused other human infection including septicemia, meningitis, wound and eye infection and urinary tract infection (Abbott and Janda, 2010). The aim of this work was isolation and identification of Aeromonas species from milk, milk products and water, Antibiotic sensitivity test for Aeromonas isolates, and investigating the plasmid profile of isolates by agarose gel electrophoresis.

\section{MATERIALS AND METHODS 1-Samples:}

A total of 350 samples of raw milk , pasteurized milk, milk products including (kareish cheese, damietta cheese and refrigerated white cheese), tap water and water of udder wash (50 samples for each) were randomly collected from supermarkets, street pedlars, dairy shops, markets and farm in PortSaid province.

All of the above samples were collected under aseptic condition and transferred immediately to Port Said bacteriology Lab in icebox.

\section{2-Bacteriological examination:}

a- Isolation and identification of Aeromonas:

Ten $\mathrm{ml}$ of each samples (10gm of kariesh cheese, damietta cheese and white refrigerator cheese) were homogenized with $90 \mathrm{ml}$ alkaline peptone water (PH8.3) for $2 \mathrm{~min}$, then incubated for $24 \mathrm{hr}$ at $30^{\circ} \mathrm{C}$ (Villari et al, 2000). A loopful from alkaline peptone water was subsequently plated on the surface of starch ampicillin agar plate and incubated for $48 \mathrm{hr}$ at $30^{\circ} \mathrm{c}$. Typical yellow colonies of Aeromonas species were purified on tryptone soya agar then stained by gram stain (A.P.H.A., 1992) and confirmed on the basis of the following test: Oxidase test, resistance to vibriostatic agent o/129, esculin hydrolysis, sugar fermentation and gas production, indole production and voges- proskaur test. Identification was performed on isolates according to the criteria of Krieg and Holt (1984) and Aerokey II of Carnahan et al (1991).

b- Antibiotic Sensitivity test for the isolated Aeromonas from milk, some milk products and water was done by disc diffusion technique (Finegold and Martin, 1982).

c- Plasmid profile technique was used for detection of Aeromonas plasmid and estimation plasmid 
DNA molecular weight (Sambrook et al, 1989).

RESULTS AND DISCUSSION

Table (1): Prevalence and distribution of Aeromonas species isolated from examined samples.

\begin{tabular}{|c|c|c|c|c|c|c|c|c|c|c|c|c|c|}
\hline \multirow{3}{*}{$\begin{array}{l}\text { Type of } \\
\text { samples }\end{array}$} & \multirow{3}{*}{$\begin{array}{l}\text { No. of } \\
\text { exam. } \\
\text { samples }\end{array}$} & \multirow{2}{*}{\multicolumn{2}{|c|}{$\begin{array}{c}\text { No of } \\
\text { positive } \\
\text { samples }\end{array}$}} & \multirow{2}{*}{\multicolumn{2}{|c|}{$\begin{array}{c}\text { No of } A . \\
\text { isolates }\end{array}$}} & \multicolumn{8}{|c|}{ Aeromonas species } \\
\hline & & & & & & \multicolumn{2}{|c|}{$\begin{array}{c}A . \\
\text { hydrophila }\end{array}$} & \multicolumn{2}{|c|}{$\begin{array}{c}\text { A. } \\
\text { caviae }\end{array}$} & \multicolumn{2}{|c|}{$\begin{array}{c}\text { A. } \\
\text { sobria }\end{array}$} & \multicolumn{2}{|c|}{ A. schubertii } \\
\hline & & No & $\%$ & No & $\%$ & No & $\%$ & $\begin{array}{l}\mathrm{N} \\
\mathrm{O}\end{array}$ & $\%$ & No & $\%$ & No & $\%$ \\
\hline 1-Raw milk & 50 & 29 & $58 \%$ & 35 & $70 \%$ & 19 & $\begin{array}{c}54.28 \\
\%\end{array}$ & 9 & $25.7 \%$ & 4 & $\begin{array}{c}11.4 \\
\%\end{array}$ & 3 & $8.5 \%$ \\
\hline $\begin{array}{l}2- \\
\text { Pasteurized } \\
\text { milk }\end{array}$ & 50 & 13 & $26 \%$ & 19 & $38 \%$ & 9 & $\begin{array}{c}47.3 \\
\%\end{array}$ & 5 & $26.3 \%$ & 3 & $\begin{array}{c}15.7 \\
\%\end{array}$ & 2 & $\begin{array}{c}10.5 \\
\%\end{array}$ \\
\hline $\begin{array}{l}\text { 3-Kariesh } \\
\text { cheese }\end{array}$ & 50 & 35 & $70 \%$ & 38 & $76 \%$ & 19 & $\begin{array}{c}47.5 \\
\%\end{array}$ & 13 & $32.5 \%$ & 5 & $\begin{array}{c}12.5 \\
\%\end{array}$ & 1 & $2.5 \%$ \\
\hline $\begin{array}{l}\text { 4- Damietta } \\
\text { cheese }\end{array}$ & 50 & 24 & $48 \%$ & 27 & $54 \%$ & 15 & $\begin{array}{c}55.5 \\
\%\end{array}$ & 7 & $25.9 \%$ & 4 & $\begin{array}{c}14.8 \\
\%\end{array}$ & 1 & $3.7 \%$ \\
\hline $\begin{array}{c}5- \\
\text { Refrigerate } \\
\text { d White } \\
\text { cheese }\end{array}$ & 50 & 20 & $40 \%$ & 24 & $48 \%$ & 7 & $\begin{array}{c}29.1 \\
\%\end{array}$ & 10 & $41.6 \%$ & 5 & $\begin{array}{c}20.8 \\
\%\end{array}$ & 2 & $8.3 \%$ \\
\hline $\begin{array}{l}\text { 6-Tap } \\
\text { water }\end{array}$ & 50 & 8 & $16 \%$ & 15 & $30 \%$ & 8 & $\begin{array}{c}35.3 \\
\%\end{array}$ & 7 & $46.6 \%$ & - & - & - & - \\
\hline $\begin{array}{l}\text { 7- Water of } \\
\text { udder wash }\end{array}$ & 50 & 34 & $68 \%$ & 42 & $84 \%$ & 27 & $\begin{array}{c}64.2 \\
\%\end{array}$ & 9 & $21.4 \%$ & 4 & $9.5 \%$ & 2 & $4.7 \%$ \\
\hline Total & 350 & 163 & $\begin{array}{c}46.6 \\
\%\end{array}$ & 200 & $57.1 \%$ & $\begin{array}{c}10 \\
4\end{array}$ & $\begin{array}{c}51.5 \\
\%\end{array}$ & 60 & $29.7 \%$ & 25 & $\begin{array}{c}12.4 \\
\%\end{array}$ & 11 & $5.4 \%$ \\
\hline
\end{tabular}

Bacteriological Examination of 350 samples of raw milk, pasteurized milk and milk products including kariesh cheese, damietta cheese and refrigerated white cheese, tap water and water of udder wash.(50 samples for each) as shown in Table (1) revealed prevalence of Aeromonas species in the collected samples: $29(58 \%)$ out of 50 raw milk samples were positive for Aeromonas species. While 13 (26\%), 35 (70\%), 24 (48\%), 20 $(40 \%)$ of pasteurized milk, kariesh cheese, damietta cheese, and refrigerated white cheese, respectively, were positive for isolation of Aeromonas species.
The highest positive samples were observed in those from water of udder wash 34 (68\%) while the lowest positive sample were recorded in tap water $8(16 \%)$. This higher percent in water of udder wash could be attributed to the wide presence of the organism in nature, in feeds, water, faeces, soil and equipment used for milking. In addition, water used for washing the udder and milking equipment is consider as a significant source of contamination and presence of motile Aeromonads in high level in raw milk because the organism can contaminate the udder via the teat, then multiply in mammary tissue 
and subsequently discharged in milk (EL-Shemawy and Marth, 1990).

The presence of mesophilic Aeromonas species in the pasteurized milk might be due to inefficient pasteurization or post pasteurization contamination during packaging of pasteurized milk as a result of unhygienic conditions during manufacture (Yucel et al, 2005). The evidence of Aeromonas species in kariesh cheese samples due to the fact that milk used in manufacture of kariesh milk usually didn't exposed to boiling or any other heat treatment. In addition due to its low salt content. In addition Bomo et al (2004) attributed the presence of Aeromonas species in water to its colonization of drinking water distribution system and production of biofilms that increase Aeromonas resistance to antimicrobial or disinfectants.

The result tabulated in Table (1) demonstrated the total number of Aeromonas isolates and frequency distribution of Aeromonas species among different sample. 35 isolates of Aeromonas were recovered from raw milk samples identified as higher percent of $\boldsymbol{A}$. hydrophila (19) $(54.28 \%)$ while lower percent of A. schubertii (3) (8.5\%). Nearly similar results were recorded by Melas et al (1999) and Henedak (2002). In contrary Akan et al (1996) could isolate A. hydrophila in $65.3 \%$ followed by $30.4 \%$ of $\boldsymbol{A}$. sobria and $A$. caviae in $4.3 \%$ from raw milk samples.
Concerning to incidence of Aeromonas species isolated from pasteurized milk as shown in Table (1). It was recognized that $\boldsymbol{A}$. hydrophila occupied the first position $47.3 \%$ while $A$. schubertii which could be isolated only in $10.5 \%$. This result is nearly in agreement with those reported by Abou- Ayana and Gamal EL Deen (2010).

Examination of kariesh cheese samples revealed isolation of 40 isolates: $47.5 \%$ belong to $\boldsymbol{A}$. hydrophila, $32.5 \%$ belong to $\boldsymbol{A}$. caviae, $12.5 \%$ belong to A. sobria and $2.5 \%$ only for A. schubertii. These findings are similar to those reported by Effat et al (2000) and Nahla (2006). While lower incidence was reported by $\boldsymbol{E} \boldsymbol{L}$ Prince (1998) and Enany et al (2004).

Results of damietta cheese revealed that $\boldsymbol{A}$. hydrophila (55.5\%) was the most predominate species in the isolated samples. followed by A.caviae $(25.9 \%)$ then A. sobria $(14.8 \%)$. While the least frequently occurring species was $\boldsymbol{A}$. schubertii (3.7\%). On the other hand $\boldsymbol{E L}$ Prince (1998) could isolate $A$. caviae followed by A. hydrophila, A. sobria from damietta cheese.

Regarding to incidence of Aeromonas species from refrigerated white cheese. As shown in Table (1) A. caviae showed highest incidence (41.6\%) followed by $A$. hydrophila (29.1\%), A. sobria (20.8\%) and A. schubertii (8.3\%). 
The results of incidence of Aeromonas species in Table (1) revealed that Aeromonas isolates that could be recorded from tap water samples distributed were between A. hydrophila (35.3\%) and A. caviae $(46.6 \%)$. These results nearly are in agreement with those reported by Burke et al $(1984 a \& b)$ and Maria et al. (2008). In contrary Manuel et al (2009) could isolate A. caviae and A. media only.

Concerning to incidence of Aeromonas species in water of udder washing, 42 Aeromonas isolates were identified as $\boldsymbol{A}$. hydrophila $(64.2 \%), \quad$ A. caviae (21.4\%), A. sobria (9.5\%) and A. schubertii (4.7\%).

Abeyta and Wekell (1988) reported that $\boldsymbol{A}$. hydrophila is commonly present in farms, feeds, water, faeces, soil and equipement used for milking, thus it

The antibiotic susceptibility pattern of Aeromonas strains isolated from all samples revealed that all isolates were sensitive to chloramphenicol and amikacin in $100 \%$ and resistant to ampicillin and colistin sulphate. The least frequent sensitivity was recorded with erythromycin. The result agreed with Awan et al (2009), Yucel et al (2005) and Nagar et al (2011). In contrary these results disagree with Altwegg and Greiss (1989) who recorded that Aeromonas strains were resistant to chloramphenicol. This study indicated that different isolates of Aeromonas strains varied in their sensitivity to antibiotics

Doxycycline

erythromycin and trimethoprim sulfamethoxazole).

Results of agarose gel electrophoresis of plasmid DNA extracted from four strains of Aeromonas in Suez Canal biotechnology lab indicated that $\boldsymbol{A}$. hydrophila, A. caviae and $A$. schubertii have only one plasmid DNA with molecular weight 2.8 kbp. While A. sobria was negative for plasmid. These results are nearly similar with those reported by Son et al (1997) and Abulhamd (2009). The presence of plasmids may present a potential public health hazard. Thus, the presence of plasmids in clinically important bacteria increases their virulence.

\section{References}

Abbott, S.L and Janda, J.M. (2010): The genus Aeromonas: taxonomy, pathogenicity, and infection. Clinical Microbiology Reviews, 23.35-73.

Abeyta, C.JR and Wekell, M.M. (1988): Potential source of Aeromonas hydrophila. J. Food Safety, 9:11-22.

Abou Ayana, I. A. and Gamal El Deen, A.A. (2010): Incidence of pathogenic Aeromonas spp. in milk and certain dairy products Collected from Dakahlia Governorate. J. Food and Dairy Sci., Mansoura University, Vol.1 (11).

Abulhamd, T. A. (2009): Characterization of Aeromonas hydrophila isolated from aquatic 
environments using phenotypic and genotyping methods. Res. J. Agriculture and Biological Sciences, 5(6): 923-931.

Akan, M.; Diker, K.S; Kocak, C.; Yildirim, M; and Bozkurt, S. (1996):

Isolation of moltile Aeromonads from raw milk Gida, 21(5): 383386.

Altwegg, M. and Greiss, H.K. (1989): Aeromonas as human pathogen. Crit. Rev. Microbiol, 16: 253-286.

A.P.H.A. (1992): Compendium of methods for the microbiological examination of foods. $3^{\text {rd }}$ Ed., Vavderzant, C. and Splittstoesser, D.F (eds.) Washington.

Awan, B.M; Maqbool, A; Bari, A and Krovacek, $K$. (2009):Antibiotic susceptibility profile of Aeromonas spp. isolated from food in Abu Dhabi, United Arab Emirates. New Microbiologica, 32: 17-23.

Bomo, A.M; Storey, M.V and Ashbolt, N.J. (2004): Detection, integration and persistence of aeromonads in water distribution pipe biofilms. J Water Health, 2(2): 83-96.

Buchanan, R.L. (1984): The (New) pathogens: An update of selected examples. Association of food and drug officials quarterly Bulletin, 48: 142-155.

Burke, V; Robinson, J; Gracey, M., Peterson, D, and Partridge, K. (1984a): Isolation of Aeromonas hydrophila from a metropolitan water supply: seasonal correlation with clinical isolation. Appl. Environ. Microbiol, 48:361-366.

Burke, V; Robinson, J; Gracey, M., Peterson, D; Meyer, N. and Haley, V. (1984b): Isolation of Aeromonas species. From an unchlorinated domestic water supply. Appl. Environ. Microbial, 48: 367-370.

Carnahan, A.M; Behram, S. and Joseph, S.W. (1991): Aerokey II: A flexible key for identifying clinical Aeromonas Species. Journal Clinical Microbiology, 29: 2843-2849.

Effat,B.A; Hosny,I.M and Dabiza,N.M (2000): Occurrence of Aeromonas hydrophila and its growth in Egyptian soft cheese.Egyptian Journal of Dairy Science, 28 (1): 1-12.

El-Prince, E. (1998): Incidence and characterization of Aeromonas species in Damietta and kariesh cheese sold in Assuit province. Assuit Vet. Med. J. Vol. 39 No. 78, July.

El-Shenawy, M.A. and Marth, E.H. (1990): Aeromonas hydrophila in foods: A review. Egyptian J. Dairy Sci, 18: 219-234. Enany, M.E., EL-Shahidy, M.S and Eid, H.M. (2004): Prevalence of Aeromonas species in raw milk and some milk product. SCVM J, V11: 455-462.

Finegold, S.M and Martin, W.J. (1982): Diagnostic Microbiology. $6^{\text {th }}$ Ed.,

C.V. Mosby Co., St Louis, Toronto, London. 
Henadak, A.A. (2002): Aeromonas hydrophila micro-organism isolated from raw milk and milk product. SC.V.M.J, Fac. Vet Med, Suez Canal University.

Holmes, P; Niccolls, L.M and Sartory, D.P. (1996): The Ecology of Mesophilic Aeromonas in the Aquatic Environment, In: The Genus Aeromonas, Austin, B., M. Altwegg, P.J. Gosling and S. Joseph (Eds.), Wiley and Sons, Chrichester, UK, pp: 127-150.

Holmberg, S.D; Schell, W.L; Fanning, G.R; Wachsmuth, I.K; Hickman-Brenner, F.W; Black, P.A; Brenner, D.J. and Farmer, J.J. (1986): Aeromonas intestinal infections in the United States. Annals Of Internal Medicine ,105(5): 683-689.

Janda, M.; Bottons, E.J and Reitano, M. (1983): Aeromonas species in clinical microbiology. Significance, epidemiology and speciation.

Diagnostic Microbiology Of Infection Diseases, 1: 221-223.

Krieg, N.R and Holt, J.G. (1984): Bergy's Manual of Systematic Bacteriology, the Williams and Wilkins, Baltmore, London.

Manuel, P; Jose, M.R; Jesus, A.S and Maria-Lusia, G.L. (2009): Occurrence of motile Aeromonas in municipal drinking water and distribution of genes encoding virulence factors. International Journal of Food Microbiology, 135(2): 158-164.
Maria Tereza , P. R; Marisa, D. B; Petra, S. S and Maria Ine ${ }^{\wedge} s$, Z.S. (2008):

Aeromonas detection and their toxins from drinking water from reservoirs and drinking fountains. Journal of Water and Health. 6: 117-123.

Melas, D, S; Papageorgiou, D.K and Mantis, A.I. (1999): Enumeration and confirmation of A.hydrophila, A.caviae and A.sobria isolated from raw milk and other milk products in Northern Greece. J food prot, 62: 463-466.

Nagar, V; Shashidhar, $R$ and Bandeka, J.R. (2011): Prevalence, characterization and antimicrobial resistance of Aeromonas strains from various retail food products in Mumbai, India. Journal of Food Science, dio: 10.111/ j: 1750-3841.

Nahla, T. Korashy. (2006): Astudy on mesophilic Aeromonas in milk and some milk products in Port Said City. J Appl Sci Res. 2(11): 10371041.

Oliver, S.P; Jayarao, B.M and Almeida R.A (2005): Food borne Pathogens in Milk and the Dairy Farm Environment. Food Safety and Public Health Implications. 2(2): 115-129.

Sambrook, J; Fritsch, E.F and Maniatis, T. (1989): Molecular cloning: a laboratory manual. Cold Spring Harbor Laboratory Press, Cold Spring Harbor, New York, 2344 pp.

Son, R; Rusul, G; Sahilah, A.M; Zainuri, A; Raha, A.R and Salmah, I. (1997): Antibiotic 
resistance and plasmid profile of Aeromonas hydrophila isolates from cultured fish, Telapia (Telapia mossambica). Lett Appl Microbiol, 24(6): 479-482.

Villari, P; Crispino, M; Montiuori, $\mathbf{P}$ and Stanzione, $\mathbf{S}$. (2000): Prevelance and molecular characterization of Aeromonas Quality, 28: 313-24. species in ready to eat food in Italy. Journal of food protection, 63: 1754-1757.

Yucel, N; Aslim. B and Beyatli, Y. (2005): Prevalence and resistance to antibiotics for Aeromonas species isolated from retail fish in Turkey. $\mathbf{J}$ Food

\section{الملخص العربي}

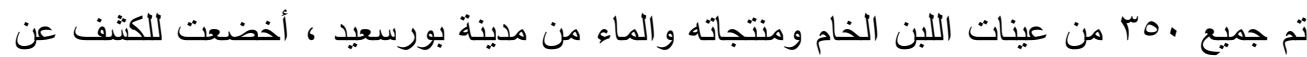

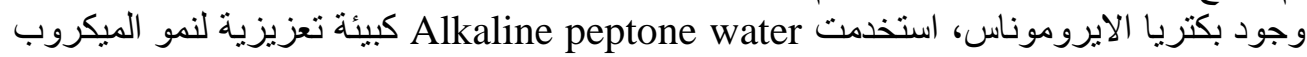

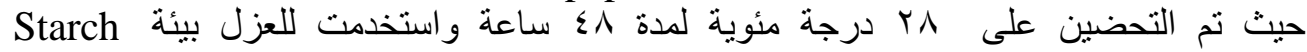

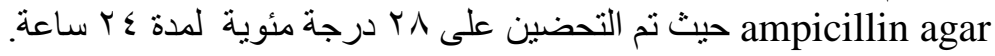

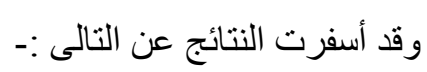

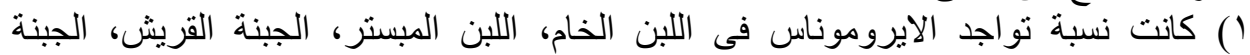

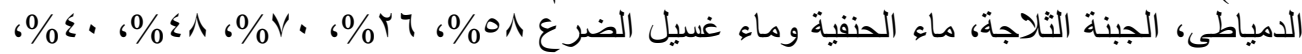

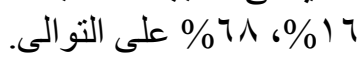

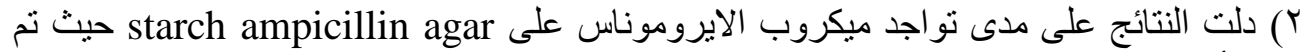

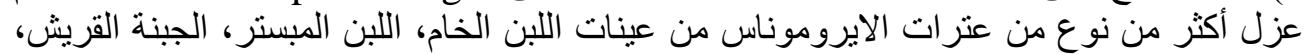

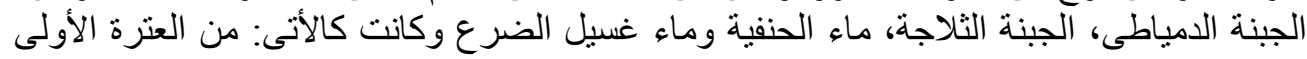

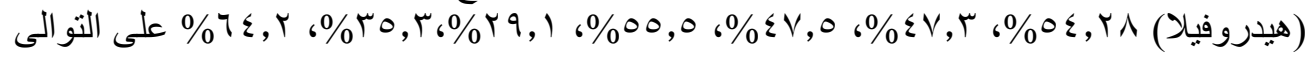

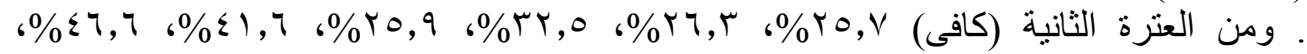

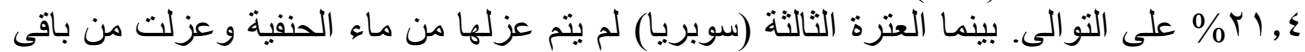

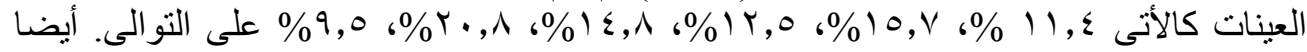

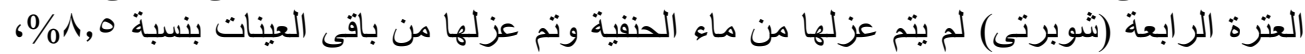

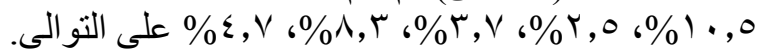

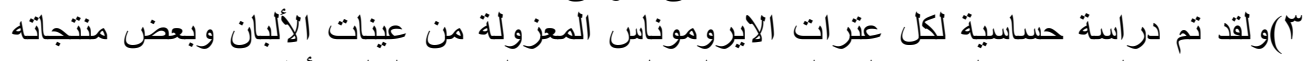

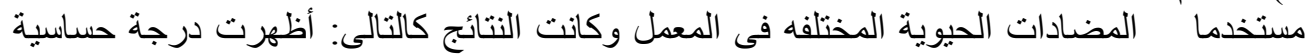

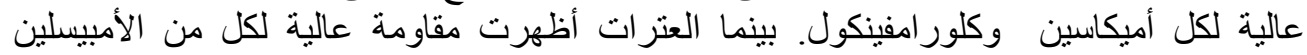

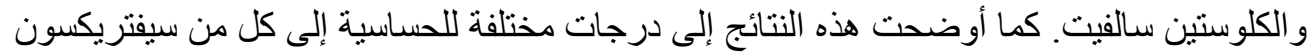

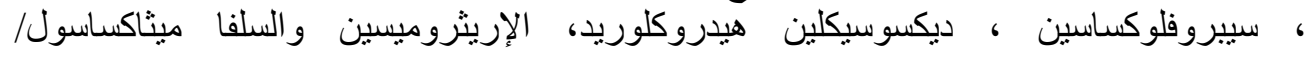

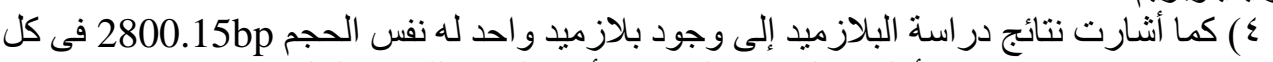

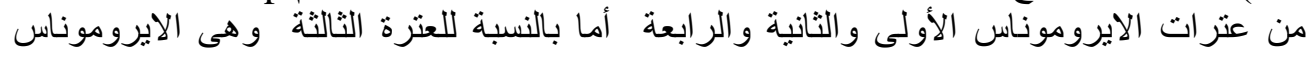

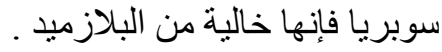

